\title{
The cultural diversity of contemporary Iraq in the light of security threats and conflicts between its components
}

\author{
Ziyad Abdulqadir ${ }^{1 \mathrm{~A}}$ \\ A University of Warsaw, Poland
}

Received: June 14, 2021 | Revised: June 20, 2021 | Accepted: June 30, 2021

DOI: $10.33445 /$ sds.2021.11.3.7

\begin{abstract}
The culture and citizenship as a right for all Iraqis as an economic and productive resource for development, the spread culture of human rights and cultural diversity in one country is beneficial. Rather, it means openness to diverse cultures that enrich human characteristics, explode the energies of creativity and participation, economic development, in order to avoid the feeling of the power superiority of the great "nation" over small nations it needs to assimilate a culture of diversity, participation, and dialogue at the grassroots and middle-class levels, as to be associated with institutions, cultural and legal structures, constitutional legislation, and economic, social and educational reforms. To end up the authority of tyranny that dominates all components, and the various local groups in their customs, traditions, languages, and ways of expressing them, requires popular awareness and an intellectual renaissance so that contributes to the transition to a new stage.

In Iraq, the most important cultural and intellectual transformations are openness to the different other, this needs to deepen the concepts of citizenship, participation, and the peaceful transfer of power according to legal legislations that confirm the theory of transition from the centrality of the state, its restrictions, conditions, especially "nationalism" in it to approaching groups, ethnic and sectarian minorities in the same country. This needs to a new awareness, studies centers to deal with the history, cultures, language of minorities, and focusing attention on developing the pillars of these minorities for their great benefit on cultural diversity within a state, as the situation in Iraq which has not taken its dimensions into leaving the centralization of the state and abandon the totalitarian methods that it still practices. The most vital question is; are the civil forces in Iraq able to take the lead in creating a cultural environment to promote confidence, a sense of citizenship and present cultural action programs that reassure the preservation of the culture of all its groups, ethnics and religious sects?

It does not seem possible at the present time due to the domination of sectarian, national, sectarian conflicts, struggles over "power" and political decision-makers. The modern experience of Iraq needs the support of international organizations and institutions. In the Middle East, Iraq has witnessed wars, bloody conflicts, and local conflicts for a hundred years, starting from the first inception, pursued minorities and groups belonging to the homeland, the most severe damages that are still suffering from the centralization, its influence, its military capacity, and the culture of arrogance and superiority over the other.
\end{abstract}

Key words: cultural diversity, ethnic conflicts, sectarian, components, modern Iraq, pluralism, security.

\section{Introduction}

In the necessities of friend-hood between peoples and nations, spreading a culture of peaceful and social coexistence, and moving away from all forms of violence, threats, and harassment of national, religious and social minorities. The peoples of the world have successful experiences in enriching the concepts of coexistence and multiculturalism, as in a number of European and American countries.

\footnotetext{
${ }^{1}$ Corresponding author: Doctoral Candidate Faculty of Psychology, e-mail: abdulqadir.ziyad@psych.uw.edu.pl, ORCID: 0000-0002-0558-7002
} 


\section{Results and discussion}

\section{Iraq}

Iraq is considered one of the most diverse countries in the world in terms of cultural and civilizational heritage, it is a country rich in cultural diversity, religiously and ethnically. The number of sects and religions coexist with each other in an area called Mesopotamia and the birthplace of ancient civilizations. Talking about the cultural diversity of Iraq needs to retreat to the background of the establishment of the Iraqi state (Mohsen Hussein, March 10, 2021). After the end of the First World War and the victory of the Allies, the United Kingdom chose the name of Iraq as a new country by merging three Vilayets "States", namely, Baghdad, Basra and Mosul of the former Ottoman, which established under the Cairo Conference, held by the British Colonial Ministry in 1921, then the Monarchy System was established. In 1932 the Iraqi Kingdom was gained independence from the United Kingdom. In 1958, the monarchy was overthrown and established the Republic system. After the invasion of the United States and its allies in Iraq in 2003, the Baath Party was removed from power and formed a new Iraqi government held parliamentary elections pluralism in 2005 (Basu, Moni, 2011-1218).

\section{Understanding the cultural diversity of Iraq}

The understanding of cultural diversity in Iraq needs to take into account the variables that calls for re-thinking state building, as a result of the new variables that were not understood in the period of the formation of the state of Iraq before World War II, in particular related to cultural identity in a multicultural of Iraqi society. The most important events of the Iraqi state at the beginning of the twenty-first century are the events of 2003 the collapse of Saddam's regime, the Islamic State control in 2014 and after ISIS. The first event is related to change and the end of the totalitarian regime in Iraq, the second event is related to the control of ISIS over many Iraqi provinces, and the third event is related to the second event, that the works after ISIS. All of these events showed a defect in the Iraqi political system's dealing with issues of cultural diversity, despite the constitutional recognition that Iraq is a country of multiple nationalities, religions and sects. Therefore, there is an opportunity to rebuild the Iraqi citizen after the war on ISIS through a policy of recognition that refers to the diversity and multiculturalism (Rahai, Qais Nasir, 2019).

\section{Cultural diversity in Iraq}

The ignorance of almost completed by the composition of the national and religious diversity in Iraq has left its impact on the way of responding and the nature of the state's interaction, and even international actors with diversity to the extent that dealing with the country has been reduced to the approach and vision of the three major groups Shias, Sunnis and Kurds. The national, religious and linguistic diversity in Iraq leaves specialists in front of a rich map that includes Christians whose identity cannot be easily summarized, as Iraqi law recognized 14 Christian sects (Saad Salloum, 2018), Sabean-Mandaeans who form a millennial culture over more than twenty centuries, and Yazidis whose religion has its roots back tens of centuries, as well as the Jews. Religious diversity in Iraq also includes religious minorities such as Kaka'is and Baha'is, who are considered among the minor religious minorities that embrace one of the modern religions in the contemporary world and finally Zoroastrians.

In addition to this religious diversity, there are the ethnic and linguistic diversity, which includes Turkmen, who are the third main ethnic group in Iraq after Arabs and Kurds, and Shabak is one of the minorities that has lived in northern Iraq for nearly five centuries. As well as the Kurdish Failis who are deployed along the border line with Iran in the Zagros Mountains and in areas of Baghdad, and the Iraqis are of African descent, and they are an ethnic minority of various African ancestry. Their ancestors were brought through the stages of Islamic history, and they settled in various places in southern Iraq. And finally, the Iraqi Caucasian tribes from Circassians, Chechnya and Dagestan (Saad Salloum, 2018).

Iraq as a country of diversity of ethnicities, religious and sectarian where lived the oldest religions, on its land the components coexisted 
together, and in it various religious and ethnic groups that were formed since antiquity time, some of them are authentic, their roots back to the civilizations of Mesopotamia, and others are settled, but they formed as a whole with the rest of the state components of the Iraqi modern state (Evan Nasser Hassan, 28-03-2021). The statistics of the Iraqi federal government do not include any questions about religious, sect, and ethnicity; However, independent sources indicate that the percentage of Arabs without sectarian discrimination constitutes $75-80 \%$ of the total population, while Kurds constitute between 15$20 \%$, and other ethnicities account for 5\% including Turkmen, Yazidis, Shabaks, Kakais, Bedouins, Romans, Assyrians, Circassians, Sabaeans, Mandaeans and Persians (Fanack, July 29, 2020). The languages spoken in the Iraqi Republic include: The official languages are Arabic and Kurdish, Turkmen (is a Turkish dialect), Syriac (is Neo-Aramaic), and Armenian are official languages in areas where native speakers of these languages constitute the majority of the population.

The following are the components and minorities of the Iraqi people:

\section{Arabs}

About three quarters of Iraqis Almost 30 million Iraqis (2010 estimates) are Arabs, they are the descendants of the invaders who invaded Iraq from the Arabian Peninsula in the seventh century. The Arabs are largely religiously divided: $80 \%$ are Shias, constituting the largest part of the population, and the remaining $20 \%$ are Sunnis (Saad Salloum, 2018). Although the Sunnis are in the minority, they dominated Iraqi politics and ruled until 2003. The Arab Shias along with the Kurds suffered from prolonged political and economic enslavement, which clearly shows the distortions in the existing political system based in Iraq due to the percentage of the total population. After the collapse of Saddam Hussein's regime, the Arabs Shia acquired prominent positions in Iraqi politics, to some extent relative to their numbers. As expected, it was difficult for Sunni Arabs to lose power and political influence after 2003. Though the two main sects within Islam, Sunni and Shia, agree on most of the fundamental beliefs and practices of Islam, a bitter split between the two goes back some 14 centuries. Despite their differences, Sunni and Shia have lived alongside each other in relative peace for most of history. But starting in the late 20th century, the schism deepened, exploding into violence in many parts of the Middle East as extreme brands of Sunni and Shia Islam battle for both religious and political supremacy (Home office, 2021).

\section{Kurds}

The Kurds constitute about $20 \%$ of the population of Iraq, their number is estimated at 8.4 million, concentrated in the northern regions called the Kurdistan Region, where they constitute the great majority of the population in the provinces of Sulaymaniyah, Erbil and Dohuk, with a distinct and major living in Kirkuk. Some of them also live in the provinces of Nineveh, Diyala and Baghdad. The Kurds are distinguished by a certain clothing and they have their own Kurdish culture and language distinctive (Joshua Project, October $20,2020)$. The Kurdish culture is considered one of the oldest cultures in the world, which was developed by successive generations who from 6000 to 5400 years BC, from the mountains, valleys and cities dwelling for them, it is noteworthy that this culture overlapped with its counterpart from Mesopotamia, where the Kurds see themselves as descendants of the IndoEuropean peoples. Therefore, the Kurds can be considered as descendants of all those who settled in Kurdistan over time, but their cultural heritage was exposed to injustice, neglect and oppression (Traditions and Heritage, 2015), or to tyranny by other dominant cultures, which led to the disappearance or destruction of important elements of the original Kurdish cultural heritage. The Kurds of Iraq constitute a distinct group that is collected by the ethnicity, culture and language that it commons with the rest of the Kurds, as for the religious aspect, the Kurds belong to a variety of faiths and religions, and most of them are classified as Sunni Muslims, a minority of Shias such Fayli, Lur, and Shabak, in addition to some of them followers of the Kaka'i and Yazidi religions (Basheer Mohamed, August 20, 2014).

At the beginning of the twentieth century, the Kurds began to think of forming an independent state as "Kurdistan". Where the Kurds in Iraq continued their struggle for independence until 
they were able to liberate three cities (Erbil, Dohuk, and Sulaymaniyah) in the uprising of 1991 and they established the Kurdistan Regional Government in 1992. After the collapse of the Baath regime in Iraq in 2003, the Iraqi Kurds were able in 2005 to establish a federal rule in their northern region under the Iraqi constitution, which established a federal republic of Iraq (Darren L. Logan, 2009). Despite the participation of the Kurds and their main prominent role in rebuilding the new state of Iraq, but political differences overshadowed the relations between the Kurds and Baghdad, and the two sides failed to reach any agreement to solve the problems between them. Therefore, on September 25, 2017, more than 92 percent of the Kurds voted to secede from the central government in Iraq in a referendum conducted by the Kurdistan Regional Government (Dilzar Salih, 29 September 2017).

\section{Christians}

The Christians in Iraq are the descendants of the Chaldeans, the Syriacs, and the Assyrians, and they have been in Iraq for nine thousand years, and they are the descendants of civilizations in Babylonia and Assyria, which is the cradle of human civilization. Christians were live in the most areas of Mesopotamia, and they were subjected to several massacres throughout history, including the massacre of the Armenians, Smel, Soriya and Anfal, as well as a major massacre during the control of ISIS over the city of Mosul (Evan Nasser Hassan, 28-03-2021). Christians are currently living in Baghdad, Nineveh, Mosul and other cities of the Kurdistan Region. Christians have a good role in cultural diversity in Iraq, one beautiful example of diversity is the role that played by the Christian public in general life in Iraq, as it often happens that the Christians of the country, by canceling joyful Christian religious occasions, because they coincide with sad Shia occasions, where Christian clergy shows to participate the grief of Shias, but the opposite never happens, with a Shiite initiative to cancel or suspend a Shiite event if it coincides with a Christian religious or grief event (Aqeel Abbas, 2 July 2020).

\section{Turkmen}

The Turkmen represent the third nationalism in Iraq, and the second in the Kurdistan region, that the Turkmen are geographically distributed in the regions of Mosul, Kirkuk, Diyala, Salah AL-Din and Erbil, as well as most of the Turkmen regions were subjected to fierce attacks by ISIS (Evan Nasser Hassan, 28-03-2021). The Turkmen speak a Turkish dialect, and have preserved their language (despite a strong linguistic Arabization policy by Saddam Hussein) but are no longer tribally organized. Turkmen historical origins in Iraq are tied, at least in part, to the role of protectors of the Ottoman empire from tribal raids. Early Turkmen were settled at the entrances of the valleys that gave access to the Kurdish areas, and this historic pacification role has led to strained relations with the Kurds. Under Saddam Hussein the Turkmen were denied cultural, linguistic or political rights. The Ba'athists replaced thousands of Turkmen (and Kurdish) inhabitants of Kirkuk and its environs with Arabs, and the community was subject to purges. Turkmen fear being left out of a future territorial settlement between Sunni and Shia Arabs and Kurds that their community is at risk of political and cultural assimilation (Turkmen, November 2017).

\section{Yezidis}

They are an ethno-religious group centered in Kurdistan and Iraq, ethnically belonging to Kurdish origin with Indo-European roots. The Yazidi religion is one of the ancient religions, and the circumstances of the Yazidis have changed with the change of times and situations that have passed through them, and this religion similar or joint with other religious components, especially Kaka'i. The Yazidi religion is a monotheistic religion, but for several centuries its followers have been subjected to other intellectual and cultural attacks in addition to campaigns of extermination such the last of which was in 2014 by ISIS because of their religious affiliation (Evan Nasser Hassan, 28-03-2021). The Yezidis consider that the "Sun" as the source of life, they have "Lalish Temple" which is located in the Kurdistan region, it is considered one of the most important and famous temples of the Yezidis in the world. Prior to the ISIS advance, Iraq's Yezidis numbered approximately 500,000 and were concentrated in Sinjar, 150 kilometers west of Mosul, with a smaller community in Shaikhan, the Kurdistan foothills east of Mosul, where their most holy shrine of Shaykh Adi is located. The Yezidis are by 
and large impoverished cultivators and herdsmen who have a strictly graded religio-political hierarchy and tend to maintain a more closed community than other ethnic or religious groups. Yezidis speak the Kormanje dialect of Kurdish and some identify ethnically as Kurds, while others view themselves as having a distinct ethnic identity as Yezidis (Yezidis, November 2017).

\section{Zoroastrianism}

Zoroastrianism is one of the oldest religions in the world whose rituals are still practiced in and around Iraqi Kurdistan. This religion was named after its founder Zoroaster. It was the official religion of the Median, Achaemenid and Sassanid empires, and it is popular in some Kurdish regions. With Kurdish identity and culture under threat from ISIS, the core principles of Zoroastrianism are finding favor with disillusioned youth in the region (Lara Fatah, 2015). Samme Dick 2019, argued that the emergence of Zoroastrianism due to a combination of the rise of the Islamic State in Iraq and the Levant in 2014, legislative change and the importance some Kurdish nationalists historically attached to Zoroastrianism as the suggested original religion of the Kurds (Samme Dick, 2019). According to the representative of Zoroastrians in the Kurdistan Regional Government, Awat Husam Al-Din, most of the Kurds were Zoroastrians before Islam, this religion was transmitted as a social inheritance, and its followers practiced their rituals in secret, in 2015 issued a law in the Kurdistan Regional Parliament, which included the recognition of Zoroastrianism as a religion, and followers of this became Religion practice their rituals freely (Evan Nasser Hassan, 28-03-2021).

\section{Kakai}

The origin of the Kaka'i religion goes back thousands of years, and its followers are concentrated in Iraqi Kurdistan. According to researcher Farhad Kakai, the Kakais are present in the Zagros Mountains region and the followers of this religion live in the governorates of Mosul, Kirkuk, Diyala and Sulaymaniyah, their number papulation is about 200,000 people in Iraq. The origin word Kakae is "Kaka", meaning "Old Brother"; where it is considered one of the oldest monotheistic religions, which believes in one God, spreads in northern Iraq, and the majority of its members are Kurdish. It is characterized by ambiguity and secrecy in relation to ideas, beliefs and ways of practicing its rituals (Kareem Shafeeq, 2019). The Kakaism is a religion independent of all religions, and it has four pillars: (honesty, purity, sacrifice and self-denial), the owners of this religion have been subjected to genocide throughout history, the last of which was the genocide committed by ISIS.

\section{Sabean-Mandaean}

Sabean-Mandaean is a non-missionary religion, does not believe in anyone entering it, and forbids marriage from outside the religion. Among its rituals are prayer, fasting, almsgiving, and baptism is one of the most important pillars of this religion. The book "Ginza Rba" (The Great Treasury) is considered the holiest book and manuscript for the Sabean-Mandaeans and the source of legislation, commandments and teachings. The Mandaeans have historically settled in southern Iraq, given the importance of water in their faith, their settlement centered around rivers. SabeanMandaeans face extinction as a people (Alhurra, 20 July 2017). Since the outbreak of violence in 2003, most Sabean-Mandaeans have either fled the country or been killed. Therefor the size of the community is estimated at less than 5,000 in Iraq. As their small community is scattered throughout the world, the Sabean-Mandaeans' ancient language, culture and religion face the threat of extinction. In 2006, UNESCO listed the SabeanMandaean language in its Atlas of the World's Languages in Danger of Disappearing. The departure of many Sabean-Mandaean religious leaders from Iraq also threatens the ability of the remaining community to retain their rituals (Sabian Mandaeans, November 2017).

\section{Armenians}

Armenians are one of the first people to convert to Christianity, specifically in the year 301 $A D$. The vast majority of Armenians live in Baghdad, the Nineveh Plain, the city of Mosul, Kirkuk and the Kurdistan Region. The Armenians speak Arabic, Kurdish and Armenian, and have contributed greatly to serving and building the country, and they are among the authentic components of society. Ethnically distinct from the rest of the population, they are culturally Iraqi (Kirkuk Now, 2020-11-10). Many displaced Armenians have settled in the relatively safer Iraqi 
Kurdistan region in recent years and their number is currently estimated about 3 thousand, and they live in Erbil, Dohuk and Zakho. The Constitution of the Kurdistan region recognizes Armenians as an ethnic component, provides the right to mothertongue education in the Armenian language, and reserves one seat in parliament for Armenians. There are at least two Armenian schools and five churches in the region (Armenians, November 2017).

\section{Jews}

There was a large Jewish community in Iraq until the early 1950s. In the 1947 census, their number was estimated at about 117,000 . The Jews lived many centuries in Mesopotamia; most of them were concentrated in urban areas, especially in Baghdad, where they controlled most of the trade. They managed to preserve the Hebrew language and their religious rites, there were also small Jewish communities in Iraqi Kurdistan, whose members spoke the Kurdish language and involved many customs with the surrounding Kurds (Fanack, July 29, 2020). When political developments and tragic events further destabilized their situation, these factors together caused massive emigration out of Iraq and go to Israel in the fifties of the twentieth century. At the present time, there are less than 250 Jews in Iraq (Asharq Al-Awsat Newspaper, March 29, 2021).

\section{Conclusions}

To preserve cultural diversity, it may need a roadmap to promote pluralism and peaceful coexistence in Iraq, that instead of theoretical work it can apply practical work to preserve and improve the multicultural process in sequential ways and steps first; legislation: It is a means of accelerating the transition towards a tolerant society, legislation can shorten the way and investigate what can be achieved. Second, the role of interfaith dialogue. The clergy may be part of the problem, but they can also be part of the solution. And third, creating curricula that are appropriate and compatible with a multicultural society. As well as promoting the rich linguistic pluralism in the Iraqi society, and

\section{Faili kurds}

Faili Kurds are an ethnic group historically inhabiting both sides of the Zagros mountain range along the Iraq-Iran border, and can be considered a cross-border population. Faili Kurds inhabit the governorates of Baghdad, Diyala, Wasit, Maysan and Babil, and work in various fields such as trade, industry and continued to move between Iraq and Iran before the First World War. The head of the Faili Kurds Association, Sami Faili, confirms that the origin of the word Faili is Baili, which means "The Brave Man", and their number in Iraq is estimated at about two million (Evan Nasser Hassan, 28-032021), they speak a distinct dialect of Kurdish, which is a sub-dialect of Luri. Unlike the majority of Kurds, who are generally Sunni Muslims adhering to the Shafi'i school of Islam, Faili Kurds are Shi'a Muslims. Their dual Shi'a and Kurdish identity have historically exposed them to stigmatization and persecution. The Faili Kurds were subjected to forced displacement during the dictatorial regimes that ruled Iraq, as nearly half a million Failis were displaced during the period from 1971 to 1980, their property was confiscated, and most of them returned to Iraq after the collapse of the Saddam's regime (Faili kurds, November 2017) but they are still living under the threat of extremist religious groups.

protecting these languages from extinction, for example; Preserving the Sabean-Mandaean spoken by the clergy in rituals, which was included in the 2006 UNESCO Dictionary of Endangered Languages, etc. One of the outcomes of this legislation is also to encourage building educational policies that enhance the knowledge of minority culture, history and languages, while ensuring the right of minorities to learn in their own languages, which form part of their identity, preserve their cultures and traditions, and in a manner that enhances the cultural diversity of a society that consists of many cultures, Thus, Iraq can face challenges and cross into a good stage of cultural diversity. 


\section{References}

Asharq Al-Awsat Newspaper, (March 29, 2021) The number of Jews in Iraq no longer exceeds the fingers of one hand. Their property is forgotte and the war profiteers are preparing to seize it. AD Issue No. 15462.

Armenians, (November 2017). Minority Rights Group, Available from: https://minorityrights.org

Aqeel Abbas, (2 July 2020) From diversity to pluralism, democracy stumbled in Iraq, Arabia Sky News, PO Box 77845, Abu Dhabi, United Arab Emirates.

Alhurra, (20 July 2017), They live in Iraq. Who are the Mandaeans? Available from: https://www.alhurra.com

Basu, Moni (2011-12-18). "Deadly Iraq war ends with exit of last U.S. troops". Available from: CNN.com.

Basheer Mohamed, (AUGUST 20, 2014), Who are the Iraqi Kurds, Pew Research Center, 1615 L St. NW, Suite 800, Washington, DC 20036, USA.

Darren L. Logan, (2009), Thoughts on Iraqi Kurdistan: Present Realities, Future Hope, ran $\&$ the Caucasus, Brill, Vol. 13, No. 1, pp. 161186.

Dilzar Salih, (29 September 2017), Facts do not know about the Kurds in Iraq, Irfaasawtak, Available from: https://www.irfaasawtak.com/iraq/2017/09/2 9/\%D8

Evan Nasser Hassan, (28-03-2021), Glimpses of the Components of Iraqi Society, Iraqi News Agency (INA).

Faili kurds, (November 2017), Minority Rights Group, Available from: https://minorityrights.org

Fanack, (July 29, 2020), Population of Iraq, Middle East and North Africa Chronicle, Available from: https://fanack.com

Joshua Project, (October 20, 2020), Available from: www.joshuaproject.net.

Home office, (2021), Country Policy and Information Note Iraq: Sunni Arabs,
Independent Advisory Group on Country Information, Independent Chief Inspector of Borders and Immigration Globe House, 89 Eccleston Square, London, SW1V 1PN, Iraq Sunni Arabs - Gov.uk.

Kirkuk Now, (2020-11-10), The Armenians in Iraq, a minority on the verge of extinction, Available from: https://kirkuknow.com

Kareem Shafeeq, (2019), 10 Information about the Kakai sect, have you heard of it? Afriat, an electronic newspaper published by the Dal Center for Research and Media Production, Cairo, Egypt.

Lara Fatah, (2015), How Iraqi Kurdistan is reversing the trend of declining Zoroastrian populations, Scroll Ground Reporting Fund, Scroll.in.

Rahai, Qais Nasir, (2019), Politics of Recognition is a Necessity for the Iraqi State In order to cultural diversity, Basra and Arabian Gulf Studies Center, Basra University, ASJP, Volume 14, Pages 11-23

Sabian Mandaeans, (November 2017), Minority Rights Group, Available from: https://minorityrights.org

Samme Dick, (2019), Rekindling the Flame: Zoroastrianism in Iraqi Kurdistan, Kurdish Studies 2:161-188. The Central and Eastern European Online Library.

Saad Salloum, (2018), Iraq's unity in diversity, Iraqi Network Magazine, Iraqi Media Network, IMN.

Turkmen, (November 2017), Minority Rights Group, Available from: https://minorityrights.org/

Traditions and Heritage, (2015), Kurdistan Land of Montine and History, Available from: http://bot.gov.krd/kurdish/about-kurdistan/

Mohsen Hussein, (March 10, 2021), 100 Years Since the Founding of the Modern Iraqi State, Azzaman Magazine, an independent international daily Arab magazine, Baghdad.

Yezidis, (November 2017), Minority Rights Group, Available from: https://minorityrights.org/ 